\title{
Effects of Task-based Language Teaching (TBLT) Approach and Language Assessment on Students' Competences in Intensive Reading Course
}

\author{
Shijun Chen ${ }^{1} \&$ Jing Wang ${ }^{1}$ \\ ${ }^{1}$ School of Foreign Languages, Zhuhai College of Jilin University, Zhuhai, China \\ Correspondence: Shijun Chen, School of Foreign Languages, Zhuhai College of Jilin University, Zhuhai, China
}

Received: January 4, 2019 Accepted: February 9, 2019 Online Published: February 11, 2019

doi: 10.5539/elt.v12n3p119 URL: https://doi.org/10.5539/elt.v12n3p119

\begin{abstract}
Task-based language teaching on the purpose of enhancing students' communicative skills and involving them actively in the authentic context has long been highlighted in recent years in tertiary English language teaching. This paper proposes a framework of task-based teaching approach and language assessment in intensive reading class based on the researcher's own teaching practice to explore positive impacts on students' competences. This is done in the context of both oral presentation and written reports of first undergraduate English major students. The research method consists of semi-structured interviews and a questionnaire with 18 questions pointing to different aspects in the learning and teaching processes, aiming to explore what impacts it has on students' competence in both second language acquisition and at cognitive level. In this empirical study, all the findings indicate that TBLT applied in Chinese English teaching class is very effective and beneficial for the enhancement of Chinese English learners.
\end{abstract}

Keywords: task based language teaching; peer assessment; interactive communication

\section{Introduction}

Task-based language teaching (TBLT) and language assessment have gained much attention in recent years. In the language teaching literature, a task can be viewed in several ways. It is structured, used in real world for communication, and usually with outcomes or specific objectives (Crookes, 1986; Nunan, 1989; Skehan, 1996a; Wills, 1996). Based on the previous literature, we drew the definition of a pedagogic task as "a goal-oriented activity involving information or opinion gap in an authentic context carried out by learner in ways of communication with predictable outcome that can be evaluated". According to Jeon and Hahn (2006), TBLT provides learners with natural sources of meaningful material, ideal situations for communicative activity, and supportive feedback allowing for much greater opportunities for language use. In addition, many researches also claimed that task-based language assessment is a crucial element in task-based language teaching. (Van den Branden, 2006b; Norris, 2009). Thus, TBLT is inseparable with a consistent assessment or evaluation (feedback) system. TBLA is not an unidirectional formative language testing with single criteria, nor one-way verbal slash written feedback focusing on error-correction provided solely by teachers. It now has a growing number of alternatives characterized by playing its role of promoting students learning process, developing learners' autonomy and self-regulation capacities, as well as enhancing cognitive competencies in sociocultural and SLA perspectives. For example, Carless (2015) developed co-assessment (also called collaborative assessment and cooperative assessment), which is a combination of teacher assessment, peer assessment and self-assessment in his study. In many research, experiments had been carried out showed that co-assessment generated positive effects on students development towards judgment (Falchikov, 1986; Stefani, 1992), and learning cognition (Hyland, 2000; Yellow \& Topping, 2001; Yang et al., 2006). Carless (2011) found that a sustainable feedback framework would support students in self-monitoring their own work independently of the tutor, which supposedly enhance students' self-regulative capacities. Hirose (2012b) surveyed EFL students in Japan concerning their perceptions of bi-modal peer feedback in the form of written feedback and oral interaction. The results showed that written-plus-spoken peer feedback is a promising combination that helps to enhance students' motivation and potentially improve their writing ability.

The literature above illustrates that task-based language teaching and task-based assessment, sometimes called 
task-based evaluation, have a crucial role in promoting students competence at cognitive and language acquisition level. However, few researches had been conducted to provide a practical example of how to implement TBLT and TBLA in teaching practice. In light of this, this study is based on a fundamental re-conceptualization of the task-based language teaching process and assessment model, aiming to discover its potential impact on students' competence. Over a period of one academic year, 8 systematically designed tasks in accordance with the context of the course were put in the place of analyzing. The paper draws on an English comprehensive reading class experience with 30 students in distributed group setting. Classes met for ninety minutes three times a week. The study's attempt is to explore students' perceptions on benefits of tasks and task-based assessment. This research is supposed to provide insights for college teachers to design and implement any systematical communicative tasks, which is of vital to develop students' competence in different perspectives.

\subsection{Framing the Systematical Designed Task and Assessment}

Wills (1996) presented a typical task circle framework for task-based learning with specific explanation on its sequencing stages and attached the importance on using language to exchange meaning. The result showed such framework provides optimum conditions for language learning. Skehan (1996) also sequence the steps which was known as "weak" forms of TBLT. Such frameworks are considered weak form on the grounds that tasks are comparable to the production stage in PPP model. In another regard, Ellis made a three-phrase task as a frame work for designing task based lessons. It consists of pre-task, during-task and post-task.More related framing tasks could be found on plenty of researcher (McCarthy, 1998; Salaberry, 2001; Nunan, 2004).

The notion of frameworks varies with pedagogy and methodology. It is hard to reach a consensus on which framework is the best and will bring about the fullest advantages. As Ellis noted in his book (2003), what constitutes the main activity of a lesson is largely a matter of perception and therefore, to some extent at least, arbitrary. Therefore, for the benefit of research project, the model of Ellis is adopted in this research except that the procedures are not implemented in the same way.

\subsection{Pre-Task Stage}

This stage is on the purpose of introducing new topics or themes of the task, preparing students with well-organized context structures and forms of language, setting up a model of what and how students will be required to carry out the task.

\subsubsection{Procedure 1. Schema-Make Students Understand the Theme}

Cook (2011) noted that the problem with reading is not just the language, but the whole process of getting meaning from text. L2 learner have "cognitive deficits" with reading that are not caused so much by lack of language ability as by difficulties with processing information in a second language. Lack of background information could be an obstacle for $\mathrm{L} 2$ learner in the processing of acquiring a second language and a reason for reducing students' motivation in reading.

Therefore, to make students understand the theme, the teacher should be in the position to supply with adequate background knowledge or schema before students tackle with the text. For example, providing printed reading materials before class with a couple of questions attached, requiring students to watch a theme-related video and make a brief summary on it. It is also advisable to assist learners do theme-based research. It is thought to develop students' receptive skills and self autonomy, as well as enhance their motivation in a higher level reading. At this point, teacher is not "knowledge provider" but "information supplier", which two items are crucial to be distinguished, because unlike in traditional model teacher does not bring knowledge to class in a unidirectional way instead they stimulate student to acquire knowledge by self-learning. The plausible interaction is between staff and students by questions and answers.

\subsubsection{Procedure 2. Explicit and Explaining--Help Students to Construct Zones of Proximal Development}

Zones of proximal development (ZDP) is about the difference between what a learner can do without help and what they can not do, in another words, between an individual's actual and potential knowledge. Vygotsky (1978) believes that the role of education is to provide learner with experiences within their ZDP, thereby encouraging and enhancing their individual learning skills and strategies. Ellis (2003) further applied this notion into task-based learning and teaching. He mentioned that tasks must be structured in a way that they pose an appropriate challenge by requiring learners to perform functions and use language that enable them to dynamically construct ZPDs. Thus, in this process, explicit instruction could be the most appropriate approach to achieve this objective as it helps students scaffolding certain knowledge based on what they already learned. Archer (2011) demonstrated three features of explicit instruction: systematic, relentless, and engaging. It is 
particularly tailored to students' learning and attention needs, which is not explanation but modeling and guided practice. Explicit instruction enables students to decode the information, comprehend them and integrate small units into meaningful wholes whose process supports learners to internalize new structures and skills.

What is the way the writer uses to carry out explicit instructions? Below is a sequence of steps setting as an example for scaffolding students' cause-effect writing device.

Table 1. Sequences of explicit instruction with examples of classroom practice

Teacher: Now, Let's find out how the author constructed the Clear explanation of what to do text.

Teacher: As we learned before, a text normally consists of Acknowledgement of learner's actual three parts, what are they? knowledge(what they already know)

Student: Introduction, body and conclusion.

Teacher: Good!

Teacher: What is the main idea in each part? Discuss with your peers and group members.

Aroused curiosity and interaction between students

Student1: Introduction part is about background information Students engagement (when, where, what)

Student2: Body part is about why Mandela chose to plant in prison.

Student3: Conclusion part is about what Mandela gained from his gardening experience.

Teacher: Now I summarize the introduction part with a single word "fact". Can you do the next two with your group members?

Student: Body is about reasons, and ending part is its result

Teacher: Good! But use synonyms to replace reason and result

\section{Student: Cause and effect}

Teacher: Good! And this is what we called as "cause-effect" writing, here are more examples.

Teacher: Now discuss with you partner, highlight cause and effect sentences in these three pieces of writing and tell your peers their ways of connection.

Scaffolding

ZDP development

Acknowledgement of learner's actual knowledge(what they already know)

Teacher's clarification on new skills

\section{Students engagement}

Examples in Table 1 demonstrated many advantages of TBLT. First, by acknowledging learners' actual knowledge, it enhanced their confidence to get in the position for new skills and strategies. Second, students' active engagement in interactive communication has been constantly developed when they tried to make sense of new information with a clear setting goal and specific instructions. Finally, it enables students to perform structures and language to dynamically construct ZDPs with teacher's assistance, resulting in internalizing new knowledge. During the sequences, the teachers understand learners' thinking, provide scaffolding and stimulate them in cognitive work, gradually helping them comprehend it. Thus, the teacher is here for guidance and careful monitoring and providing immediate affirmation constantly.

\subsubsection{Procedure 3 Preparation Activities}

Learners at this stage can be given enough time to plan how to perform the task. Ellis (2003) illustrated two major methodologies options; one is that the students simply are given the task work plan and left to decide for themselves what to plan, while the other is that they are given guidance in what to plan. For my concern, I developed a compromise solution for this stage. Students need to meet the basic task requirements on the purpose of developing either linguistic or cognitive competence, but they are left to plan what content to put in the place and how they will perform the task. The example of planning procedures is illustrated in Table 2 . The task is an interview about punctuality. 
Students were first introduced to the idea of an interview with a topic question. They were distributed to interviewees in different identities in case of overlapping. During this process, students were provided with strategic instructions like "discuss with your group members on interview questions beforehand.", or language instructions "use the vocabulary in your textbook". This part gives additional exposure to topic-related inputs and increase students' experience of the target language in use. Task preparation usually lasts for 3 to 4 weeks. It's of great importance to introduce guided planning instructions as detailed as possible. Foster and Skehan (1996) found that when students were given detailed guidance they tend to prioritize content with resulting gains in complexity when they performed the task. As for its condition, after the interview, each group need to present it in front of the class in oral English and hand over a written report afterwards. Before their performance, students will be required to discuss assessment items either with teachers or peers. This step should not be omitted as it guided a direction of how their performance will be judged and evaluated, for example, when the item "if your group members were equally contributed to the task" were put in the evaluation format, it is plausible for task-takers to take it into consideration and distribute their duties properly, which effectively prevents the scenario that only one or two members being in charge of every performance. Table 2 is an example of detailed sequence with rich instructions and sufficient communication.

Table 2. Sequences of an interview activity

\begin{tabular}{ll}
\hline Guided planning & $\begin{array}{l}\text { Students were introduced to the idea of an interview with the question "What is } \\
\text { your attitude towards punctuality" } \\
\text { Oral presentation, written report }\end{array}$ \\
\hline Planning time & 3 weeks \\
Conditions & Oral presentation; written report \\
Procedures & Group work division \\
peer assessment training & Discuss assessment items. \\
\hline
\end{tabular}

\subsection{The During-task Phrase}

This phrase demonstrates how tasks being performed by students and what they should do during this session.

\subsubsection{In-Class Presentation}

Group presentation: Usually students in each group were given approximately 20 minutes in total to deliver a speech with the content of the process of preparation, the interviews with shared opinions, and the findings after the interview. The content of their report largely depends on what insights they have on different issues.

Individual duties: Students report their findings separately in the form of a prepared speech or power-point presentation within 3 minutes. Either in group or individual presentation, the audience is encouraged to propose any critical questions after the presentation if they have any to challenge the speaker. For example, the unidentified items or new words, the incomplete content of presentation, or logical fallacy. It has a great many benefits for both listeners and speakers through in-class observation. First, considering on-the-spot feedback, it helps the speakers to notice errors they made or overlooked language points in presentation. Second, it effectively gets students a lot more involved in other students' presentation. Furthermore, it facilitates the development of the listeners' logical thinking.

For example, in one in-class presentation, whose task is to design a course syllabus for primary students, the speaker (student A) claimed that the syllabus our group designed is best suitable for primary students because it is interesting with many games to play instead of overwhelming homework to do, then one of the listeners (student B) challenged the speaker with the question "Why playing interesting games would be best suitable for primary students?" The speaker failed to give a reasonable response on the spot, but she reflected in her self-evaluation as followings, "I should think over and give a more convincing opinion next time". This example showed that challenging questions from peers may increase the students' sense of self-improvement. Thus, teachers should set up models and encourage students to get more involved in.

\subsubsection{Teacher Assessment, Peer Assessment and Self-Assessment}

When groups are making presentation, the teacher and the rest of students have to conduct a formative assessment on a technology basis. Many researchers have applied various online tools to support peer assessment 
and self assessment (Raban and Litchfield 2007; Luxton-Reilly 2009), which proved to be less time consuming than paper work.

Students can enter the previously discussed assessment criteria online beforehand. It would enforce them to acknowledge those assessment criteria, in accordance with which, adjusting their performance, and to which extent develop their self-regulated capacities.

\subsubsection{Criteria of Tasked-Based Assessment}

Language assessment criteria have been constantly adjusted based on different types of tasks and its performances. For example, group working tasks will be assessed considering the factor of contribution equally to the task to grantee each student develop the sense of teamwork spirit and actually evolved in the tasks for separate onus. However, this criterion will be removed if it is an individual performance. Nevertheless, most task criteria cover the following aspects: content, organization and delivery.

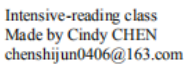

Peer Evaluation Form

This is an opportunity to grade your peers and yourself in terms of group interaction and performance. Please reflect carefully on these criteria,then evaluate your peers or yourself. Add any additional comments below. Seal in an envelope and return to the teacher.

\begin{tabular}{|c|c|c|c|c|c|c|}
\hline Criteria & Poor & Fair & Average & Good & Outstanding & What to improve \\
\hline \multicolumn{7}{|l|}{ Content } \\
\hline 1. Quality of Content & 1 & 2 & 3 & 4 & 5 & \\
\hline 2. Originality and complexity of project & 1 & 2 & 3 & 4 & 5 & \\
\hline 3. Support main ideas & 1 & 2 & 3 & 4 & 5 & \\
\hline 4. Clear conclusion(s) & 1 & 2 & 3 & 4 & 5 & \\
\hline \multicolumn{7}{|l|}{ Organization } \\
\hline $\begin{array}{l}\text { 5. Appropriate use of authentic materials, visual } \\
\text { pictures or video clips }\end{array}$ & 1 & 2 & 3 & 4 & 5 & \\
\hline 6. Logical flow of ideas & 1 & 2 & 3 & 4 & 5 & \\
\hline 7. Cooperation with team members & 1 & 2 & 3 & 4 & 5 & \\
\hline 8.Each one contributes equally to the project & 1 & 2 & 3 & 4 & 5 & \\
\hline \multicolumn{7}{|l|}{ Delivery } \\
\hline 9. Accuracy and appropriate use of language & 1 & 2 & 3 & 4 & 5 & \\
\hline 10. Timing and pacing & 1 & 2 & 3 & 4 & 5 & \\
\hline 11.Use of eye contact,gestures and movement & 1 & 2 & 3 & 4 & 5 & \\
\hline 12.Confidence & 1 & 2 & 3 & 4 & 5 & \\
\hline 13.Rapport with and sensitivity to audience & 1 & 2 & 3 & 4 & 5 & \\
\hline 14.Satisfactory answers when required & 1 & 2 & 3 & 4 & 5 & \\
\hline
\end{tabular}

answers when required

$70 \#$ as its total

Comments on the performance:

Sample of assessment criteria of a group-work on presentation 
1. [Content]Did the speech have the audience"hooked"by its introduction part?

\begin{tabular}{|c|c|c|c|c|}
\hline - Fair & - Poor & Average & Good & Outstanding \\
\hline \multicolumn{5}{|c|}{ 1. [Content] Was the content informative? Was there sufficient use of relevant fact and examples? } \\
\hline - Fair & - Poor & Average & Good & Outstanding \\
\hline \multicolumn{5}{|c|}{ 2. [Content] Were the main ideas clearly stated with one basic theme? } \\
\hline - Fair & Poor & Average & Good & Outstanding \\
\hline \multicolumn{5}{|c|}{ 3. [Content] Did the speaker have a thought-provoking opinion? } \\
\hline - Fair & - Poor & Average & Good & Outstanding \\
\hline \multicolumn{5}{|c|}{ 4. [Content] Was the speech ended with a clear and sound conclusion? } \\
\hline - Fair & Poor & Average & Good & Outstanding \\
\hline \multicolumn{5}{|c|}{ 5. [Organization]Did the speech have clear steps and logical order. } \\
\hline - Fair & - Poor & Average & Good & Outstanding \\
\hline \multicolumn{5}{|c|}{ 6. [Organization]Did the speaker tie the speech together with effective transitions? } \\
\hline - Fair & Poor & Average & Good & Outstanding \\
\hline
\end{tabular}

7. [Organization] Speech is complete with introduction, body, and conclusion. Adequate time devoted to each division within 3 minutes.

\begin{tabular}{|c|c|c|c|c|}
\hline - Fair & Poor & Average & Good & Outstanding \\
\hline \multicolumn{5}{|c|}{ 8. [Delivery-Language Style] Was the language precise, grammatically correct and vivid? } \\
\hline - Fair & Poor & Average & Good & Outstanding \\
\hline
\end{tabular}

9. [Delivery-Language Style]The words were put together well to convey meaning without appearing to be memorized.

\begin{tabular}{|c|c|c|c|c|}
\hline - Fair & Poor & Average & Good & Outstanding \\
\hline 10. [Del & 1 Delivery] & e sufficient $\mathrm{v}$ & a rate, pause & ch? \\
\hline - $\quad$ Fair & - $\quad$ Poor & - Average & - Good & Outstanding \\
\hline
\end{tabular}

Sample of assessment criteria of an individual-work on presentation

1. How do you evaluate the speaker's pronounciation?

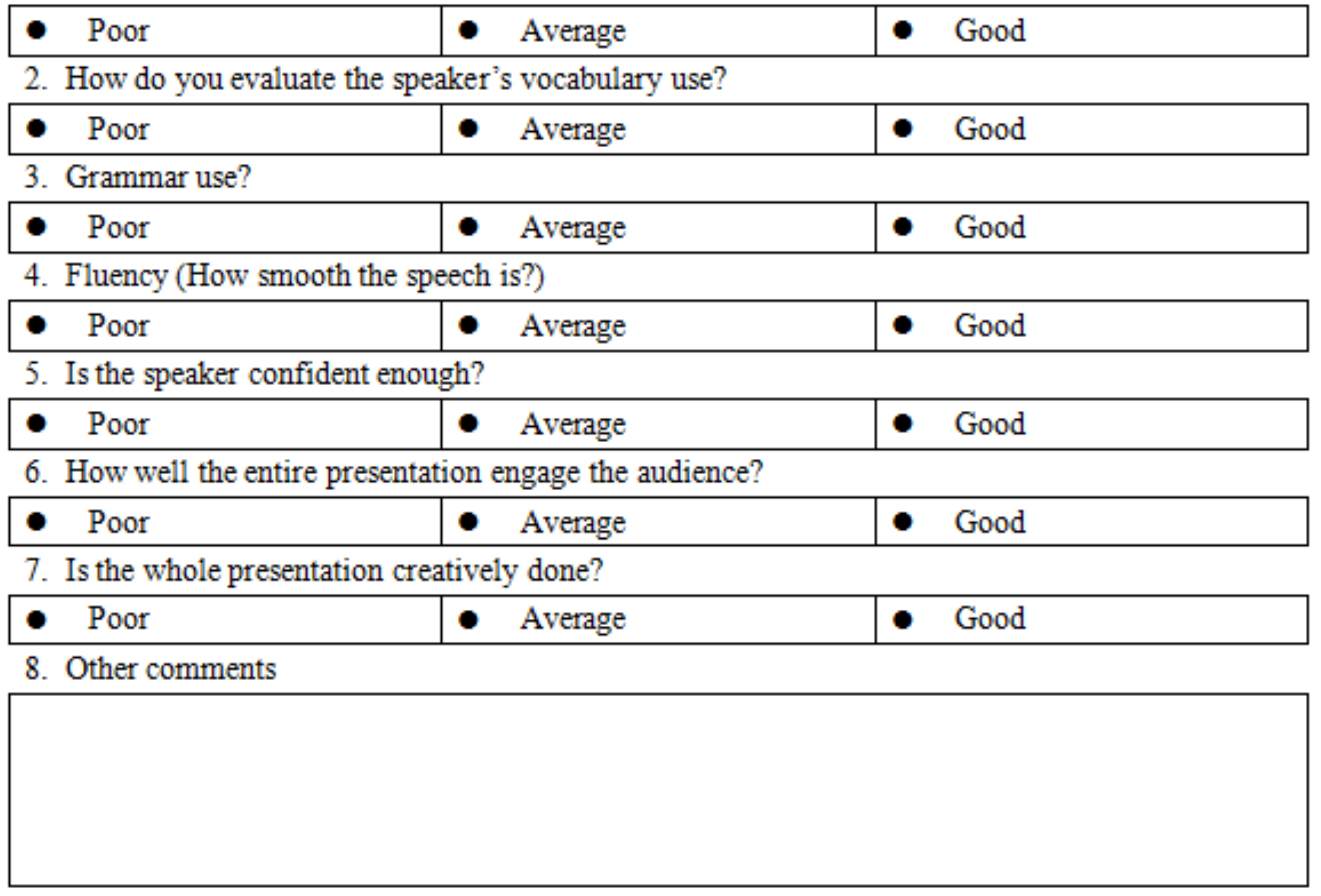

Sample of assessment criteria of an individual-work on presentation

1. The above pictures are samples of three different tasks with different items of criteria, which were established on a goal-orientated basis. Criteria items were adjusted in each time, which highly depending on its tasks and 
students feedback on previous assessment. It follows the principle of complexity-accuracy-fluency in TBLT, which are frequently used in task performance description by many researchers (Skehan 1989, Ellis 2003).

Post-task phrase: Assessment and evaluation (feedback)

Feedback has long been regarded as essential for the development of second language (L2) writing skills, both for its potential for learning and for student motivation.(Ken Hyland\&Fiona Hyland 2006) Post-task will mainly focus on self reflections on tackling the tasks and evaluations consist of peers evaluation and teacher evaluation. This includes:

1) Students write down a self-reflection on the process of how to conduct the task, and their general performance in the "during-task" phrase.

2) Students write down a peer evaluation for their peers.

3) Teacher writes down a teacher evaluation for each group in three different dimensions: a) Comments, b) Language Focus; c) In-class Presentation.

In the comment section, the constructed teacher evaluation has placed great stress on the complexity of the task and the richness of students' performance, as well as their strength and weakness. The content of comments section follows the principle of acknowledgement, praise and suggestions.

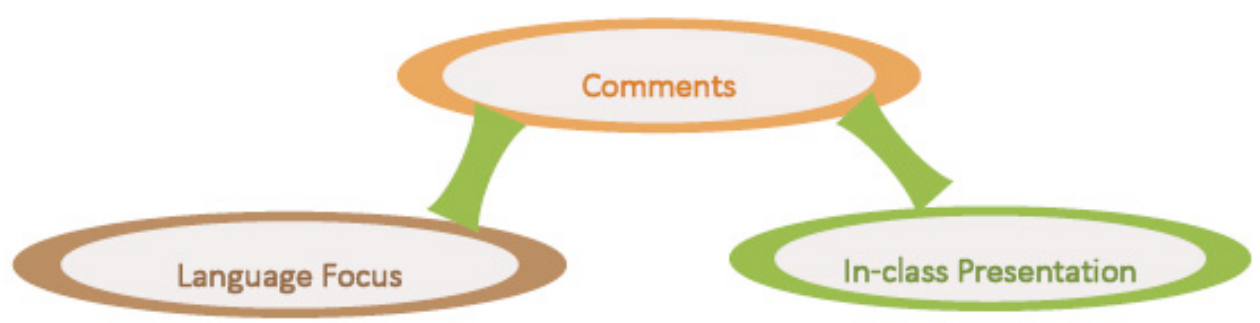

Picture 2. Structure of teacher's evaluation

Normally the evaluation will contain the following sequence as a A-P-C module.

1) A refers to Acknowledge what they have done.

2) P refers to either Praise or Problems .

3) C means critical questions proposed by teachers expecting to be responded later on.

Sample of Comments

Your group had a dramatic performance on the video, which is hilarious and cute. You've also asked the dorm-keepers a bunch of thoughtful questions. These questions are different and meaningful with careful thoughts. I hope that you would benefit from not only the practice but also dorm-keepers' answers.

$\rightarrow$ (Acknowledgment)

All your team members are hard working and able to complete it carefully and completely.I do appreciate your quality work to do it well and everyone's contributions to the dubbing except that I am a little concerned about your language accuracy. Some language being used in the subtitles are directly translated from Chinese into English which sounds very Chinglish. So double check your translation before type it as your subtitle.

$\rightarrow$ ( Praise, Problems and Suggestions)

I do understand how hard it could be to do all those interviews and dubbing and translation work all together. Even if some peers were confused about the cutting which made the video image repeated many times, I personally believe it is much clear to present dorm-keepers different opinions out on each questions and make the comparison with one another. I suppose you had struggled it with even more work than other groups. In that case, you earn your score.

$\rightarrow$ (Sympathy)

In terms of the summary part, I think you have already did a great job to generalize those opinions. While maybe you could do better next time if categorize them a little bit. Have a content indicating what you are going to say 
first, and follow the sorts one by one. Lastly, give some of your opinions based on this interview. For example, you could start with: Today we are going to talk about 4 things......first, The process of the interview Second, similar and different opinions of dorm-keepers Third, our opinion on punctuality and activity. Lastly, What did you learn from it. $\rightarrow$ (Input new knowledge)

The first part acknowledged what they have done, following with constructive suggestions. It's plain to see that language used in this comment are positive and encouraging instead of criticizing, such as thoughtful and hard working. Besides suggestions are given in an acceptable way by saying "maybe you could...."; "I personally believe", not "you should", which is much better than make students take it as an obligation. Such scaffolding provided by the teacher helps to build the students confidence and motivation to which extend enhancing their task process in the next round of tasks, and helped to build up a trustworthy relationship between the teacher and students. Just as Carless (2016) claimed that relational aspect of feedback are salient in that feedback is an aspect of interpersonal communication. Comments are vary with tasks, which should by no means made as the discussed sequences and forms. Oral comments are also effective and less time consuming.

The second section of feedback stressed the importance on the accuracy of learner's language through error corrections. Last part is to evaluate learners' task-performance in pronunciation, intonation, sentence stress as well as non-language features in a speech delivery, such as confidence and other non-linguistic strategies. Each student's performance will be recorded for the evaluation of their oral language competence.

A combined co-assessment and evaluation enable greater focus on formulation and monitoring. Learners are also enabled to give and receive reflections from different perspectives, which is expected to stimulate their autonomy and motivation.

\section{Summary}

The above mentioned process offered a framework of TBLT with detailed processes. An overview of this framework can be seen in Diagram 1. Some characteristics of TBLT should be pointed out in this framework: 1) Pre-task is significant for inputting new information to learners, which means tasks can not be carried out with no meaning and no target language. Just as Nunan (2001) claimed, reception should come before production and extensive opportunities for listening and reading should precede speaking and writing. 2) Technology-facilitated tasks is particularly applicable in a large-sized English teaching context in China. For example, tools such as Xmind can be used to organize the structure of texts, Wechat groups with assigned tasks can be used for discussion, while Wechat Public Platform allows students to publish their own work and get comments from people outside classroom. WJX.cn is a website for collecting and analyzing data, and it can be used in co-assessment stage. 3) Under such framework of TBLT, teacher's role has been changed dramatically. The teacher has come to play the role of a task-designer, material provider, a collaborator and an evaluator.

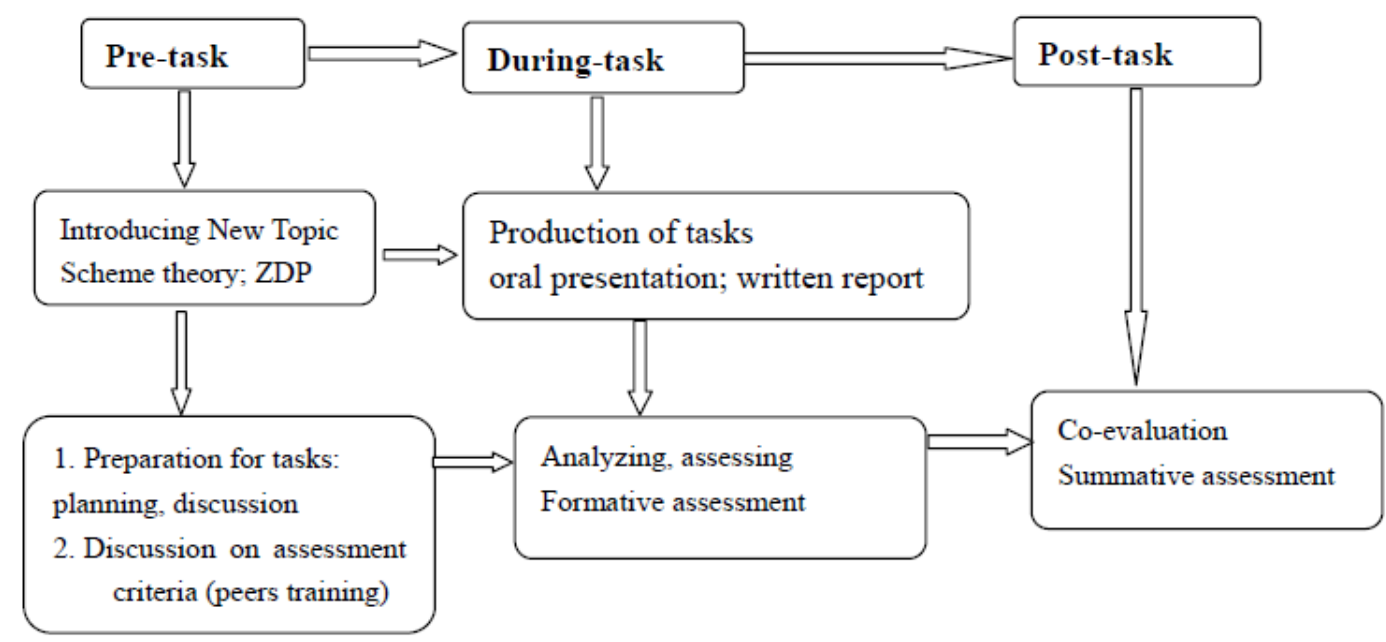

Diagram 1. Framework of TBLT 


\section{Research Questions}

The study addressed the following research questions:

1) In which aspect of competence does the participant improve over a year TBLT approach in the Intensive-Reading courses?

2) What types of tasks will bring positive effects in their English learning processes and why so?

3) What does the learner think of the assessment and evaluation system?

\section{Methodology}

\subsection{Participants}

Thirty one students between the age of 18 to 20 were enrolled in the course, 5 boys and 26 girls, whose first option in choosing major is English language. The average scores of their English language test in College Entrance Examination is 122 points out of 150 in total, which was considered at intermediate level.

\subsection{Grouping}

The arrangement of seating was random initially owing to a lack of comprehensive learning of each individual. Yet over the time passing by, deliberately switching deskmates occurred considering student levels of oral English skills, dispositions and capacities including creativity, communication skills, and organizational abilities. Some irresistible conditions existed in the course of research processing such as group members withdraw from school, new members being placed in the class, and students incidentally asking for leave with one or two undone tasks left. Hence the raw data were not completely evenly-collected, but it would not have much severe effect on the implication of the research. Each group guaranteed with a boy and 3 to 5 girls on the grounds that boys in this classes were extrovert and thought to activate the group as a whole. The hypothesis has its way that gender difference would enhance the effects of grouping.

\subsection{Research Instrumentation}

To investigate what competences have been enhanced by this TBLT framework and its influential factors, the study uses a combination of interview data, learners' portfolio and questionnaires. Data-collecting began from September 2017 to June 2018, lasting 28 teaching weeks with 4.5 hours for each week and 1.5 hours for each class. All recordings and tasks were made during scheduled classes by the writer who took over both roles of teacher and researcher.

The following instruments were used in this study:

\section{1) Questionnaire and interviews}

The questionnaire with several open questions and scale problems has been designed by the researcher, aiming at investigating students' perceptions on the effects of TBLT in three dimensions including motivation and attitudes, competences and language skills. Also the researcher has conducted a face-to-face interview with all participants.

2) Students portfolio and classroom observation

All task performances had been recorded for the evaluation by video typing or reports. Both e-portfolio and paper files had been developed, which includes paper work, video records, revised PPT, posters, as well as assessment records based on the tasks.

\subsection{Data Analysis}

The first research question is which type of tasks do students prefer and why? Four types were put into a multiple question, including interviews, making posters, impromptu speeches and designing (a travel plan, a syllabus, or a pair of brand-new shoes). Hence, as it shows in Table 8, there were 26 students $(76.67 \%)$ and 9 students $(30 \%)$ put designing and making posters as their options. As for reasons underlying such choices, they can be summarized as followings: First, designing stimulates their innovation and creativity which enables them to put new ideas into practice. Second, designing is a long process of learning during which they were provided with more opportunities to discuss and negotiate with team members and search for various back-up materials on one's own initiative. Lastly, it is interesting and has close connection with real life. Other tasks such as interviews and impromptu speeches were also considered as challenges by some students $(23.33 \%$ for both) to take because these tasks allow them to communicate with different people and know their thoughts which could be very useful in their future jobs. It is obvious that diverse tasks can be quite influential in turning students into autonomous self-regulating learners, building their interpersonal capacities and enhancing their motivation of 
both linguistic and non-linguistic learning. "Designing" is a task which highlights critical thinking, problem-solving ability and teamwork competences. Interviewing carries rich opportunities to learners in communicating with people holding different minds and thoughts, which shapes learners' way of thinking. Tasks applied in this teaching practice shed lights on authenticity, meaning-focused and student-centered qualities. Both type D and type B in Figure 3.2 are tasks with high cognitive demand and more complex communication.

Table 3. Preferences on types of tasks, $\mathrm{N}=30$

\begin{tabular}{lll}
\hline A. Interviews & $23.33 \%$ & 7 \\
\hline B. Making posters & $30 \%$ & 9 \\
C. Impromptu speeches & $23.33 \%$ & 7 \\
D. Designing & $76.67 \%$ & 26 \\
\hline
\end{tabular}

In the anonymous questionnaire, 3 open-ended questions was handed out to students to get their perceptions on what effects TBLT can bring to their English learning procedures. The questions are: 1) What have you improved by TBLT in writing? 2) What have you improved by TBLT in speaking? 3) What have you improved by TBLT in reading comprehension? Students gave their answers freely on the above three open questions. Some of the standpoints are summarized in the following table.

Table 4. Students viewpoints on effects of TBLT

Effects of TBLT in speaking

\section{Fluency}

2. I had less fear to speak out my opinion in front of other people.

3. I was less sacred of making mistakes or embarrassment.

4. I was able to talk more than before.

5. My interaction and quick response has improved.

6. I've learned some words and expressions that can be used on a daily basis.

7. Pronunciation and intonation

8. Logic

Effects of TBLT in writing

1. I made less grammatical mistakes.

2. I've learned how to make a well-organized writing.

3. I've learned to use some advanced vocabulary and figure of speeches in my writing.

4. I've developed a good habit of making an outline before writing.

5. Logic and cohesion

6. I have developed my thoughts.

7. Advanced words, expressions and sentence patterns

8. Not so much $(4 / 30)$

Effects of TBLT in reading comprehension

1. I gained some new thoughts and ideas from different texts.

2. I have extended my vision in different areas.

3. I learned many new words and expressions which cleared up the blocks of reading.

4. The ability of analyzing

5. Deep thinking

6. I can better understand the main idea and cultural differences revealed in a text. 
7. The reading speed had been increased.

From all these perspectives, it's clear to notice that TBLT had bring many positive impact on students language competences in speaking, writing and reading comprehension aspects. In this practice class, more than half of the students classified themselves as introverted people. Some of these students claimed that their challenge in English learning especially in speaking is partially because of their personality that they are very much afraid of making mistakes and being mocked by others. While others also said they don't speak their opinion out is because they don't know what to say. Yet TBLT provides rich instructions and materials on speaking to deduce their intentions and anxieties. TBLT approach boosts students self-confidence which proved to be the best predictor of language proficiency. (Clement, 1986). Linguistic self-confidence contributed to learning in foreign language learning situations where the learners had little contact with the L2 outside of the classroom. (Clement Dornyei \& Novels, 1994) Either being required to communicate with team members in a small group or give a summary speech in front of the whole class, they gradually developed a positive attitude in English speaking and some may even reach the goal of fluency to some extent. Cook (2011) mentioned that the goals of language teaching include changing people's attitudes towards other cultures and using second language effectively. In reading aspect, students are in the position to accept cultural and ideological frames from different perspectives, which may help them become critical thinkers and insightful readers. The schema theory applied in this reading practice class added up new information, accounted for comprehension and raised learners' cultural awareness. Students also learned to think deep in reading a text instead of merely focusing on language, which makes a meaning-focused not language-focused class. The writing part clearly demonstrated that learners' logical thinking and organizing ability has been trained and enhanced, though a few students found no improvement. These three open-ended questions offered the answer to what impacts will TBLT bring on students language competence.

By comparing the performance in two speaking assessment and recorded video, students are found to be more confident and willing to share their thoughts and opinions with either the teacher or their peers. Learners' performance had been appeared to be produced greatly in complexity, fluency and proficiency.

Furthermore, data analysis will be laid on other aspects of competences as followings.

Tablet 5. Students perceptions on tasks (Question 1 to Question 7)

\begin{tabular}{llll}
\hline Questions & $\mathrm{M}$ & $\mathrm{SD}$ & $\mathrm{N}$ \\
\hline 1. Some tasks are closely related to the real life. & 4.1 & 0.83 & 30 \\
2. I gained different skills by finishing tasks. & 4.2 & 0.75 & 30 \\
3. I think those skills are useful in my future job and life. & 4.27 & 0.68 & 30 \\
4. To finish each task, I had to do a lot of research in English online. & 4.23 & 0.62 & 30 \\
$\begin{array}{l}\text { 5. I did all tasks because I was interested in different topics and wanted to know } \\
\text { more about them. }\end{array}$ & 4 & 0.86 & 30 \\
$\begin{array}{l}\text { 6. I would work harder to improve myself as I don't want to make the whole team } \\
\text { lose points because of me. }\end{array}$ & 4.27 & 0.68 & 30 \\
7. I need to use plenty of target languages in finishing tasks. & 4.03 & 0.71 & 30 \\
\hline
\end{tabular}

Question1-6 demonstrates that students have generally responded positively toward designed tasks. They acknowledged the authenticity of tasks and practical advantages of these tasks which developed some prospected non-linguistic skills, such as logical analysis approaches, collaboration skills, interpersonal communication and specific techniques, namely, video editing, constructing, and dubbing. In the task-conducting processes, actual language use was also promoted when students have more chances to do research or talk to people in English, as it shows in Question 7. It also reflected that the TBLT approach somehow spurred learners' instructional motivations in the process of learning which appears to be very much powerful in the context where learners have no opportunities to interact with target-culture members as investigated by much of the research (Gardner and Lambert 1972; Masgoret and Gardner 2003). Question 4-5 rests on learners' intrinsic motivation with which learners' curiosity for new knowledge is aroused and sustained. And as a result learners gain pleasure and internal satisfaction from those task experiences which also guarantee the learners' activity engagement. 
Table 6. Students perceptions on grouping and cooperative learning (Question8 to Question13)

\begin{tabular}{llll}
\hline Question & $\mathrm{M}$ & $\mathrm{SD}$ & $\mathrm{N}$ \\
\hline 8. I need to communicate with others a lot in doing these tasks. & 4.23 & 0.76 & 30 \\
9. I like to work with my team members and share my thoughts with them. & 4.13 & 0.72 & 30 \\
10. I am not afraid of giving a speech in small groups. & 4.03 & 0.84 & 30 \\
11. I would like to offer help to my team members whenever he/she need it in English learning. & 4.43 & 0.67 & 30 \\
12. My team members always encourage me to volunteer answers in our English class. & 4.2 & 0.70 & 30 \\
13. Before each task, our team would spend time in discussion and plan our steps properly. & 4.1 & 0.83 & 30
\end{tabular}

Studying in groups is a way of cooperative learning. Table 2 elaborates specific interpersonal relations enhanced by TBLT via group work as a form of cooperative learning. Research on classroom cooperative learning has been proved to be effective to produce positive outcomes (e.g. Kagan 1995; Liang 2002). It suggests that cooperative learning in the form of groups significantly enhanced learners' oral communication competence and the affinity between its participants, and generalized active participation and the real-life social interaction.

Except what demonstrated in the questionnaire, the class observation also revealed learners minor change in each time. Take Student A for example, in the first speaking assessment, she talks with the teacher quite nervously, repeating a simple word over five times to finish a sentence and avoiding eye contact with the teacher. As time went by, under the encouragement of group members and group speech practice(each group member has to give a speech in front of the rest), the student volunteered to give speeches in a more fluency way. I made a summary of her improvement in the face-to-face interview:

I think I am more confident than before. I am not afraid of making mistakes because my group members always make mistakes and we do not blame them for that. I should practice my oral English more and improve myself in the future. I think our team is the best.

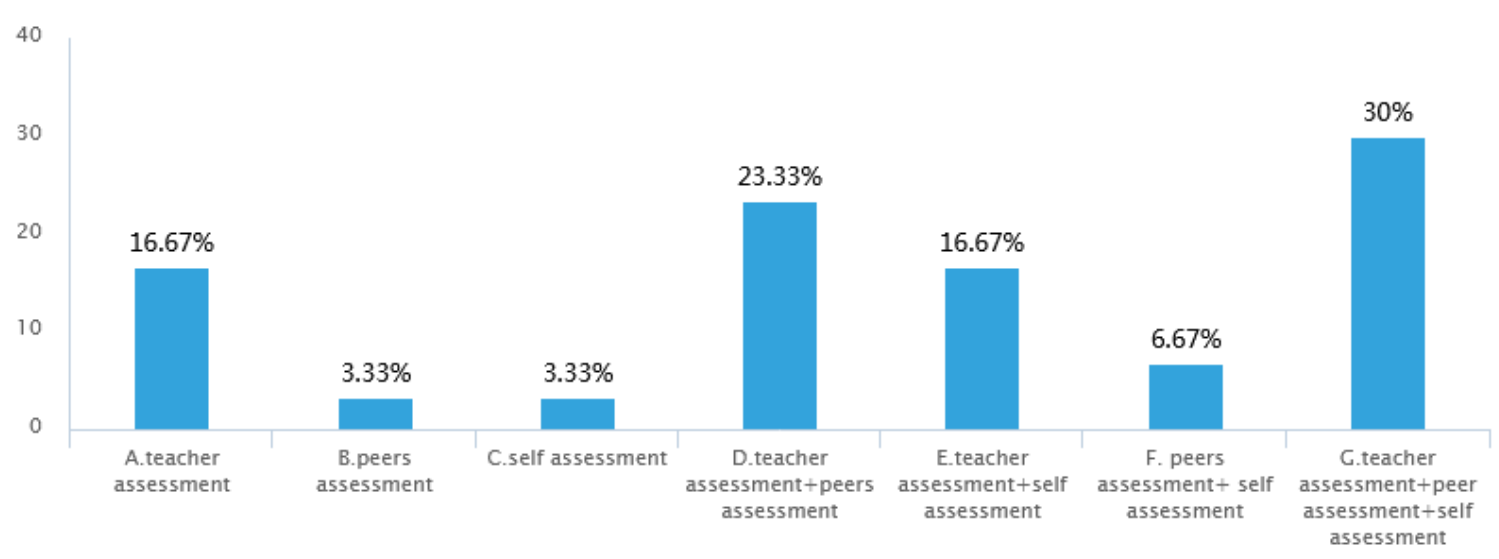

Figure 1. Question 14. Which assessment do you prefer?

Table 7. Students perception on co-assessment (Question15 to Question17)

\begin{tabular}{llll}
\hline Question & $\mathrm{M}$ & $\mathrm{SD}$ & $\mathrm{N}$ \\
\hline 15. I enjoy peer assessment because I can learn different views except teacher's. & 3.77 & 0.76 & 30 \\
16. I like peer assessment because I can observe others' work and learn from other learners. & 3.73 & 0.85 & 30 \\
17. I like self assessment because I can reflect on my homework. & 3.7 & 0.86 & 30 \\
\hline
\end{tabular}

The last part investigates learners' perceptions on assessment in TBLT. As it displays in Table 3, 9 out of 30 
students $(30 \%)$ chose co-assessment that is teacher assessment, peer assessment and self assessment. And 7 students $(23.33 \%)$ hold the opinion that teacher's and peer assessment are a good combination for evaluation. Only 2 students $(2.33 \%)$ reported that they would choose either peer assessment or self assessment. This chart reflects that teacher assessment is irreplaceable and plays a more significant role than the other two in the assessment system. Either interviews with students or data derived from Q14-16 reveals the fact that students was in less favor of peer assessment and self assessment (Mean $<4)$. Many students spoke their attitudes freely on peers and self assessment. Although some students hold a positive opinion towards peer assessment and self assessment, taking it as a way of learning and enhancing critical thinking, others are oppose to these two. Some of the standpoints against these two are summarized as followings: 1) I don't like peer assessment because it's hard to get/give specific suggestions, some of which are generalized. 2) Either self assessment or peer assessment are quite similar in each time. They are tedious and not constructive at all. 3) To make peer assessment and self assessment are too much time-consuming. 4) I don't like self assessment is because I am at a low level of self-cognition and I am not confident enough. From all these perspectives, it is plain to see students admits the importance of assessment and its various forms, yet which one to choose and how to make it effective should give proper concern.

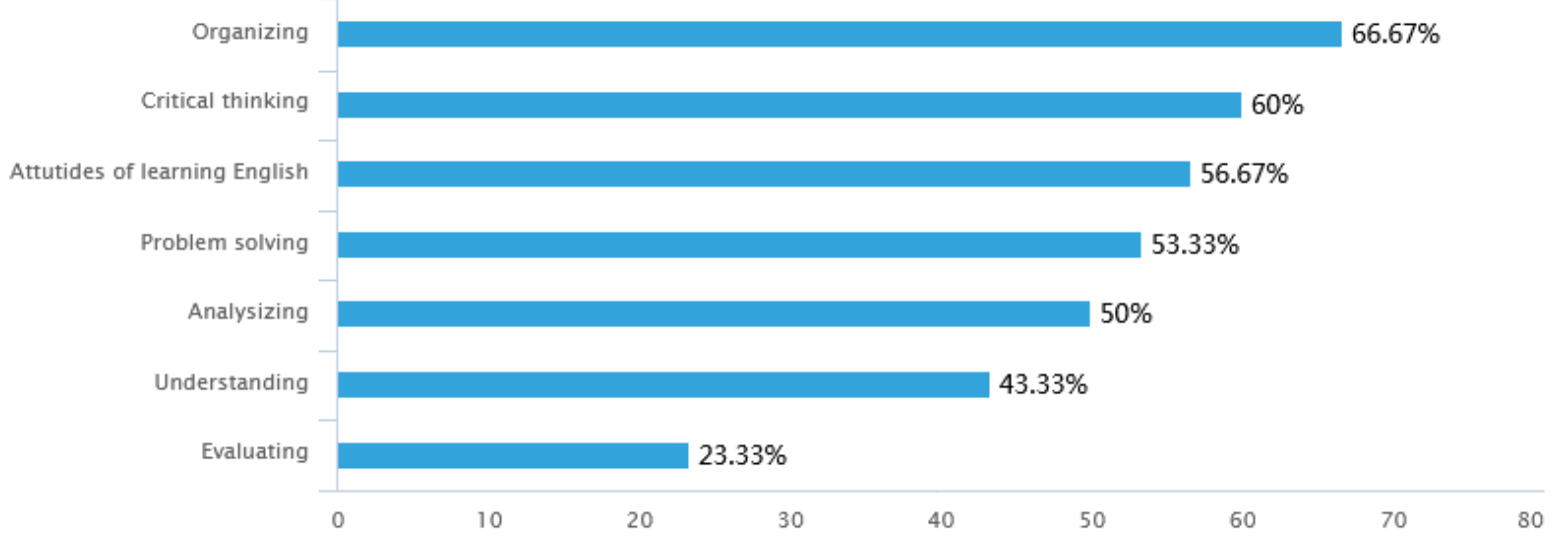

Figure 2. Question 18. Which items do you think you have improved or changed by doing tasks over the past terms? (Multiple Choice)

The last question, Question 18, offers a generalized non-linguistic competence that has been improved through TBLT based on students personal views. As it shows in the chart, organizing, critical thinking and attitudes of learning English ranks on the top three. The next follows with problem solving capacity and the ability of analysizing a problem. Students evaluating expertise receives the least recognition.

\section{Limitations}

The study was limited as followings:

i. Many factors which proved to make influences in second language acquisition had not been taken into consideration for detailed analysis such as gender differences, personality traits and levels of learners' language proficiency.

ii. This experiment was conducted based on the researcher's own teaching practice with comparatively fixed number of students, so no experience or control group had been set up for research comparison.

iii. The teaching objective of intensive reading course in the department is to develop learners' whole-person competence instead of training their specific skills. Assigned tasks are vary with different focuses. Therefore, the study did not provide enough quantitative data on learners' language competence enhancement.

\section{Implications for English Teaching}

TBLT framework can be taken as one of the contributing factors to reconfigure current pedagogy and curriculum. Yet there are some points to notice. First, since students have accepted different methodologies before being enrolled in the college, it could be a challenge for them to take TBLT completely and develop an independent learning habit. Thus, TBLT should be well-organized and designed in the curriculum, serving for different 
teaching objectives so as to lessen their repellent. Second, before each task a clear goal or a desired outcome as learning motivation should be pointed out, making learners realize the objective of each task. Third, task-based teaching involves a high level of creativity and dynamism, which is also a challenge for teachers who have been taught by traditional teacher-centered methodology and have very limited access to it, in that case, teachers should be familiarized with this approach either by some relevant training such as TESOL, TEFL, and CELTA or published guidelines. In addition, even if TBLT carries the features of meaning-focused tasks, authenticity and social communication, it by no means understates the production of each context, like the theme or values involved in and its language use. Thus, a ideal combination of real-life tasks and output of theme-focused context is a must. Some tasks may not be interesting or enjoyable, but they could be very useful in the whole process of English learning. However, obvious enjoyment by the students is not necessarily a sign that learning is taking place. (Cook, 2011). Some tasks could be even complicated and challenging, which may leads to learners' passive attitudes towards conducting a task. Hence, teacher should transfer their role of instruction-giver to a psychological assistant, consoling learners whenever their negative emotion occurs. In terms of co-assessment in the last phrase of tasks, teachers should exemplify the contents and standards of assessing, and help learners to develop evaluation consciousness and expertise. As Xu and Carless(2016) reviewed in their study, teachers need to provide guidance on assessment requirements (Evans, 2013), to help students generate or use criteria (Rust, Price, \& O' Donovan, 2003), to teach them how to analyze and use exemplars (Hendry Armstrong, and Bromberger 2012) and to clarify the student role as an active participant (Evans, 2013).

\section{Conclusion}

The primary purpose of this study is to construct a framework of TBLT approach and an assessment system serving for this methodology based on the researcher's own teaching practice. In the finding part, the study investigates the effects of TBLT on the development of students' competence in the perspectives of thinking, doing, cognition and second language acquisition. I suggest the framework of TBLT in the intensive reading class should be consisted of three tasks, including pre-task, during task and post-task. Pre-task stage is a preparation for tasks in which the topic or theme will be introduced and students will be offered with sufficient information to bridge the cultural or language gap. Before a designed task conducted by students, a systematic sequence of carrying out the task and criteria of assessment will be noted as well. The next comes to during task stage when students, usually in groups, will perform it in the way of oral presentation or written report. Meanwhile, the rest of peers and teacher would assess their performance in a formative assessment. Last step is the post-task stage which can also be regarded as the reflection stage. Both teacher and students need to conduct a evaluation for another group. The author formulates three components of evaluation report including comments, language focus and in-class presentation, which matches up with complexity, accuracy and fluency in TBLT. Comments are supposed be positive with constructive suggestions to support future tasks and facilitate learners' motivation and confidence.

The second part of this article probe effects of TBLT in this teaching practice from students perceptions. It is found in this study that tasks require innovation, decision making and teamwork are most popular among students. Decision-making is significant in the learning process, just as Bachman (1964) indicated that involving learners in decision-making tended to lead to increased motivation and thereby, to increased productivity.

The designed tasks spur the development of new ideas and involve abundant opportunities to access the target language, besides since the task is conducted within a group, it helps to enhance the interrelationship between students. The benefits and effects of TBLT in this study were elaborated in both linguistic and non-linguistic aspects. Firstly, TBLT develops learners' capacity of self-improvement and self-autonomy. It also encourages learners' intrinsic motivation. Second, TBLT provides a cooperative learning environment which simultaneously enhances learners' interactive communication skills and self-determination. TBLT improves learners' organizing skills, critical thinking and changes their attitudes of English learning. Assessment system is an inseparable part in TBLT. And teacher assessment should go before self- and peer assessment.

This article manifests that most of students are in favor of TBLT because of its real-life authenticity and communicative interactions. It changed the passive, teacher-centered class into an active, student-centered class, which highly enhanced students' engagement in a second language learning, especially in China where learners have little chance to expose themselves to an English speaking environment. Though advantages of TBLT are there, it should be applied sensibly taking many factors into consideration, including levels of participants, teaching materials, feasibility of tasks, curriculum, time settings and teacher's capability and personality. 


\section{References}

Archer, A., \& Hughes, C. (2011). Explicit Instruction: Effective and Efficient Teaching. NY: Guilford Publications.

Bachman, J. (1964). Motivation in a Task Situation as a Function of Ability and Control over Task. Journal of Abnormal and Social Psychology, 69, 272-81. https://doi.org/10.1037/h0046503

Carless, D., Salter, D., Yang, M., \& Lam, J. (2011). Developing sustainable feedback practices. Studies in Higher Education, 36(4), 395-407. https://doi.org/10.1080/03075071003642449

Carless, D. (2015). Exploring learning-oriented assessment processes. Higher Education, 69(6), 963-976. https://doi.org/10.1007/s10734-014-9816-z

Carless, D. (2016). Feedback as dialogue (pp. 1-6). Encyclopedia of Educational Philosophy and Theory. https://doi.org/10.1007/978-981-287-532-7_389-1

Clément, R., \& Dörnyei, Z. (1994). Motivation, Self-Confidence, and Group Cohesion in the Foreign Language Classroom. Language Learning, 44, 417-448. https://doi.org/10.1111/j.1467-1770.1994.tb01113.x

Cook, V. (2011). Second Language Learning and Language Teaching. Foreign Language Teaching and Research Press.

Crookes, G. (1986). Task classification: A cross-disciplinary review. In Technical report No. 4: Center for second language classroom research. Honolulu: University of Hawaii.

Ellis, R. (2003). Task-based language learning and teaching. Oxford: Oxford University Press.

Ellis, R. (2016). The Study of Second Language Acquisition. Shanghai: Shanghai Foreign Language Education Press. https://doi.org/10.1017/S027226311600005X

Evans, C. (2013). Making Sense of Assessment Feedback in Higher Education. Review of Educational Research, 83(1), 70-120. https://doi.org/10.3102/0034654312474350

Falchikov, N. (1986). Product comparisons and process benefits of collaborative peer group and self-assessments. Assessment and Evaluation in Higher Education, 11, 146-166. https://doi.org/10.1080/0260293860110206

Foster, P., \& Skehan, P. (1996). The Influence of Planning and Task Type on Second Language Performance. Studies in Second Language Acquisition, 18(3), 299-323. https://doi.org/10.1017/S0272263100015047

Gaedner, R., \& Lambert, W. (1972). Attitudes and Motivation in Second-language Learning. Rowley, MA: Newbury House.

Hirose, K. (2012b). Written feedback and oral interaction: how bimodal peer feedback affects Japanese EFL students. The Journal of Asia TEFL, 9(3), 1-26.

Hyland, K. (2000). Disciplinary discourses: Social interactions in academic writing. London: Longman.

Hyland, K., \& Hyland, F. (Eds.). (2006). Feedback in Second Language Writing: Contexts and Issues. New York: Cambridge University Press. https://doi.org/10.1017/CBO9781139524742

Jeon, I. J., \& Hahn, J. W. (2006). Exploring EFL teachers' perceptions of task-based language teaching: A case study of Korean secondary school classroom practice. Asian EFL Journal, 8(1), 8.

Kagan, S. (1995). We can Talk: Cooperative Learning in the Elementary ESL Classroom. Retrieved from www.ericfacility.net/databases/ERIC-Digests/ed382035.html

Liang, T. (2002). Implementing cooperative learning in EFL teaching: Process and effects. Retrieved August 2010, from http://www.asian-efljournal.com/Thesis_Liang_Tsailing.pdf

Luxton-Reilly, A. (2009). A systematic review of tools that support peer assessment, Computer Science Education, 19(4), 209-232. https://doi.org/10.1080/08993400903384844

McCarthy, M. (1998). Spoken Language and Applied Linguistics. New York: Cambridge University Press.

Min, H. (2014). The Effects of Task-Based Teaching Approach on College Writing Classes. Studies in Literature and Language, 9(3).

Norris, J. (2009). Task-based teaching and testing. In In M. Long, \& C. Doughty (Eds.), The handbook of language teaching (pp. 578-594). Oxford, UK: Blackwell. https://doi.org/10.1002/9781444315783.ch30

Nunan, D. (1989). Designing Tasks for the Communicative Classroom. Cambridge: Cambridge University Press.

Nunan, D. (2004). Task-Based Language Teaching. Cambridge: Cambridge University Press. 
O’Donovan, B., Rust, C., \& Price, M. (2016). A Scholarly Approach to Solving the Feedback Dilemma in Practice. Assessment\& Evaluation in Higher Education, 41(6), 938-949. https://doi.org/10.1080/ 02602938.2015.1052774

Price, M., Handley, K., Millar, J., \& O’Donovan, B. (2010). Feedback: All that Effort, but What is the Effect? Assessment \& Evaluation in Higher Education, 35(3), 277-289. https://doi.org/10.1080/0260293090354 1007

Raban, R., \& Litchfield, A. (2007). Self and peer assessment in group work using TeCTra. In ICT: Providing choices for learners and learning. Proceedings ascilite Singapore, 884-886.

Rust, C., Price, M., \& O’Donovan, B. (2003). Improving Students' learning by Developing Their Understanding of Assessment Criteria and Processes. Assessment \& Evaluation in Higher Education, 28(2), 147-164. https://doi.org/10.1080/02602930301671

Salaberry, R. (2001). Task-Sequencing in L2 Acquisition. Texas Papers in Foreign Language Education, 6(1), $101-112$.

Skehan, P. (1996a). A framework for the implantation of task-based instruction. Applied Linguistics, 17, 38-62. https://doi.org/10.1093/applin/17.1.38

Stefani, L. A. J. (1992). Comparison of collaborative, self, peer and tutor assessment in a biochemistry practical, Biochemical Education, 20, 148-151. https://doi.org/10.1016/0307-4412(92)90057-S

Van den Branden, K. (Ed.) (2006). Task-based language education: From theory to practice. Cambridge, UK: Cambridge University Press. https://doi.org/10.1017/CBO9780511667282

Vygotsky, L. S. (1978). Mind in society: The development of higher psychological processes. Cambridge, MA: Harvard University Press.

Willis, J. (1996). A Framework for Task-based Learning. ELT Journal, 60, 1-4.

Xu, Y., \& Carless, D. (2016). Only True Friends Could be Cruelly Honest: Cognitive Scaffolding and Social-affective Support in Teacher Feedback Literacy. Assessment and Evaluation in Higher Education.

$\mathrm{Xu}$, Y., \& Carless, D. (2017). 'Only true friends could be cruelly honest': Cognitive scaffolding and social-affective support in teacher feedback literacy. Assessment \& Evaluation in Higher Education, 42(7), 1082-1094. https://doi.org/10.1080/02602938.2016.1226759

Yang, M., Badger, R., \& Yu, Z. (2006). A comparative study of peer and teacher feedback in a Chinese EFL writing class. Journal of Second Language Writing, 15(3), 179-200. https://doi.org/10.1016/j.jslw.2006. 09.004

Yellow, F., \& Topping, K. J. (2001). Collaborative writing: the effects of metacognitive prompting and structured peer interaction. The British Journal of Educational Psychology, 71(Pt 2), 261-82.

Zhu, Q., \& Carless, D. (2018). Dialogue within peer feedback processes: Clarification and negotiation of meaning. Higher Education Research \& Development. https://doi.org/10.1080/07294360.2018.1446417

Appendix I. Questionnaire

\section{Part I Open-ended questions (Interviews)}

1. What have you improved by TBLT in writing/speaking/reading comprehension?

2. Which type of tasks do you like best? And why?

A. Interview

B. Making Posters

C. Impromptu speech in class

D. Designing (syllables, fashion design, travel plan)

WHY? 


\section{Part II Questionnaire}

\begin{tabular}{l|l|l|l|l}
\hline Strongly Disagree & Moderately Disagree & Undecided & Moderately Agree & Strongly Agree \\
1 & 2 & 3 & 4 & 5 \\
\hline
\end{tabular}

1. To finish each task, I had to do a lot of research in English online.

2. I did all tasks because I was interested in different topics and wanted to know more about them.

3. I prefer competition in tasks because winning makes me happy while losing lets me down.

4. I learned my strengths and weaknesses by doing different tasks.

5. I have a clear goal in each task.

6. I needed to communicate with others a lot in doing these tasks.

7. I like to interact with strangers in society and know their thoughts and ideas.

8. I would work harder to improve myself because I don't want to make the whole team lose points because of me.

9. Some tasks are closely related to the real life.

10. I gained different skills by finishing tasks.

such as

11. I think those skills are useful in my future job and life

12. I like to work with my team members and share my thoughts with them.

13. I like the collaborative learning environment.

14. I would like to offer help to my team members whenever he/she need it in English learning.

15. My team members encourages me to volunteer answers in our English class.

16. Before each task, our team would spend time in discussion and plan our steps properly.

17. I need to use plenty of target languages in finishing tasks.

\section{Assessment}

I prefer in assessment part.
A. teacher assessment
B. peer assessment
C. self assessment
D. teacher assessment+peer assessment
E. teacher assessment + self assessment
F. teacher assessment + peer assessment + self assessment

18. I like peer assessment because I can learn different views except teacher's.

19. I like peer assessment because I can observe others' work and learn from other learners.

20. I like self assessment because I can reflect on my homework.

21. I don't like peer assessment/self assessment because

(Note: Questions are randomly arranged for research purpose.)

Appendix II. Tasks

\begin{tabular}{|l|l|l|}
\hline Topics & Tasks & Procedures \\
\hline $\begin{array}{l}\text { 1. Meeting } \\
\text { people }\end{array}$ & $\begin{array}{l}\text { 1. Impromptu speech: } \\
\text { The origin of my family name and } \\
\text { given name } \\
\text { Oral task }\end{array}$ & $\begin{array}{l}\text { a. Each student should introduce their names in front of his own } \\
\text { group(1-4) } \\
\text { b. Students mingle and collect five students' name story; } \\
\text { c. Each group select a representative to share it in class via public } \\
\text { speaking }\end{array}$ \\
\hline
\end{tabular}




\begin{tabular}{|c|c|c|}
\hline & Group+Individual work & \\
\hline & $\begin{array}{l}\text { 2. Public Speaking: Etiquette in } \\
\text { countries } \\
\text { Oral task } \\
\text { Group work }\end{array}$ & $\begin{array}{l}\text { Each group will present their work on Etiquette in different country } \\
\text { by visual assistant PPT } \\
\text { (countries are randomly selected) }\end{array}$ \\
\hline \multirow[t]{5}{*}{ 2. Half a Day } & $\begin{array}{l}\text { 1. Impromptu speech: } \\
\text { On My First Day of College } \\
\text { (past tense practice) } \\
\text { Oral task } \\
\text { Individual work }\end{array}$ & $\begin{array}{l}\text { a. Teacher setted up a model first; } \\
\text { b.Students were required to give a speech } \\
\text { based on three key words in which past tense is a must(1-4); } \\
\text { c. Peers should take notes of each others' speech; } \\
\text { d. Each group selected one representative to deliver the speech } \\
\text { about his peer's story in front of the class }\end{array}$ \\
\hline & $\begin{array}{l}\text { 2. Write an proposal: } \\
\text { Ways to courage people } \\
\text { Written task } \\
\text { Individual work }\end{array}$ & $\begin{array}{l}\text { Each student should conduct a writing on how to courage frustrated } \\
\text { people based on } 2 \text { copies of reading materials }\end{array}$ \\
\hline & $\begin{array}{l}\text { 3. Write a convincing letter } \\
\text { Written task } \\
\text { Individual work }\end{array}$ & $\begin{array}{l}\text { a. Class was splitted in two division-parents and children. } \\
\text { "Parents" group(15) wrote to convince children group to go to } \\
\text { school; "children group"(15) should give reasons for their } \\
\text { reluctance; } \\
\text { b. peers evaluation: each "parent" and "children" will select the one } \\
\text { randomly to give assessment based on content, language, and } \\
\text { grammar of its writing }\end{array}$ \\
\hline & $\begin{array}{l}\text { 4. Road description } \\
\text { Written task } \\
\text { Group work }\end{array}$ & $\begin{array}{l}\text { a. Each group was required to depict road scenery on campus with } \\
\text { picture attached; } \\
\text { b. Two copies of road description material for after-reading, each } \\
\text { students should went through its meaning,new words, and } \\
\text { rhetorical description } \\
\text { c. Polish the original draft with peers assistant }\end{array}$ \\
\hline & $\begin{array}{l}\text { 5. Design a syllabus for a primary } \\
\text { school }\end{array}$ & $\begin{array}{l}\text { a. Each group was required to } \\
\text { design an impressive teaching syllabus to attractive students; } \\
\text { Each group was consist of a headmaster and three to four course } \\
\text { teachers; } \\
\text { The head teacher was to present background information of school, } \\
\text { including teaching facilities, teachers'qualification, routine } \\
\text { activities; } \\
\text { "Course-teacher" was to present a well-designed teaching syllabus } \\
\text { and certain relevant activities; } \\
\text { b. Peers was given a format to evaluate four groups performance. } \\
\text { c. Each group conducted a self-evaluation for reflection. }\end{array}$ \\
\hline 3. Discussing & 1. Make a timetable & Read teacher's timetable, and make a personal one \\
\hline
\end{tabular}




\begin{tabular}{|c|c|c|}
\hline \multirow[t]{4}{*}{ daily life } & $\begin{array}{l}\text { Oral task } \\
\text { Group work }\end{array}$ & $\begin{array}{l}\text { a. Interview with people from all walks of life, } 6 \text { groups in } \\
\text { general-teachers,roommates, foreigners,dorm-keeper,vendors; } \\
\text { b. Make a video over the interview with subtitles; } \\
\text { c. Public speaking - people's attitude towards punctuality; } \\
\text { d. peer assessment and self assessment based on the evaluation } \\
\text { format(25); } \\
\text { e. Writing:self evaluation+peers evaluation+teachers } \\
\text { evaluation+response feedback }\end{array}$ \\
\hline & $\begin{array}{l}\text { 3. Read relevant materials } \\
\text { BBC news report } \\
\text { "Why some people are always } \\
\text { running late" }\end{array}$ & $\begin{array}{l}\text { Student was given a copy of reading material for back-up } \\
\text { information after the interview }\end{array}$ \\
\hline & $\begin{array}{l}\text { 4. Interview upon English } \\
\text { learning method } \\
\text { Oral task+Written task } \\
\text { Individual work }\end{array}$ & $\begin{array}{l}\text { a. Students was required to interview an appointed senior } \\
\text { after-class; } \\
\text { b. Write an article about the interview and share it with peers } \\
\text { c. Collect articles and create a class magazine "Learner" }\end{array}$ \\
\hline & $\begin{array}{l}\text { 5. Impromptu speech Topic: My } \\
\text { weekends } \\
\text { Oral task } \\
\text { Group work+Individual work }\end{array}$ & $\begin{array}{l}\text { a. Each student was required to give a speech in front of each } \\
\text { group(1 to 4) } \\
\text { b. Each group should select one representative to deliver the speech } \\
\text { in front of the whole class; } \\
\text { c. Teacher should give delayed feedback and on-the-spot assistant }\end{array}$ \\
\hline \multirow[t]{4}{*}{$\begin{array}{l}\text { 4. Describing } \\
\text { things } \\
\text { Sub-themes: }\end{array}$} & $\begin{array}{l}\text { Oral task } \\
\text { Group work }\end{array}$ & $\begin{array}{l}\text { a. Each group was required to draw or make a 3D robot; } \\
\text { b. Switch the robot with other group and depict peers' robot with } \\
\text { color and shape phrases }\end{array}$ \\
\hline & $\begin{array}{l}\text { 2. Conduct "Found"and "Lost" } \\
\text { posts } \\
\text { Written task } \\
\text { Group work }\end{array}$ & $\begin{array}{l}\text { a. Teacher's explanation on found and lost poster } \\
\text { b. Teacher hides } 6 \text { objects in different places of the classroom; } \\
\text { c. Students were required to find them out and depict its } \\
\text { shape,color, material and location orally; } \\
\text { d. Students were required to write both "found" and "lost" post }\end{array}$ \\
\hline & $\begin{array}{l}\text { 3. Make up a story } \\
\text { Written task } \\
\text { Individual work }\end{array}$ & $\begin{array}{l}\text { a. Students were required to make up a story based on the color } \\
\text { phrase, such as "I'm green","'blues music","in the pink" } \\
\text { b.Teacher's grading. }\end{array}$ \\
\hline & $\begin{array}{l}\text { 4. Customer-Complaint-Letter } \\
\text { Written task } \\
\text { Individual work }\end{array}$ & $\begin{array}{l}\text { a. Students were required to read } 3 \text { samples of complaint letter } \\
\text { b. Students were required to write a complaint letter based on their } \\
\text { own purchasing experience }\end{array}$ \\
\hline
\end{tabular}




\begin{tabular}{|c|c|c|}
\hline & $\begin{array}{l}\text { 5. Shoes design warehouse } \\
\text { Written task } \\
\text { Group work }\end{array}$ & $\begin{array}{l}\text { a. Teacher's text explanation } \\
\text { b. Students were required to login on Amazon.com and search for } \\
\text { relevant information; } \\
\text { c. Students were required to design a pair of shoes with detailed } \\
\text { item information }\end{array}$ \\
\hline $\begin{array}{l}\text { 5.The Kindness } \\
\text { of Strangers }\end{array}$ & $\begin{array}{l}\text { 1. Travel plan } \\
\text { Oral task } \\
\text { Group work }\end{array}$ & $\begin{array}{l}\text { a. Each group was required to conduct a summer travel agenda } \\
\text { with considerations of accommodations, tourist attractions to visit, } \\
\text { and transportation etc. } \\
\text { b. Each group make a presentation and compete for "The Finest" } \\
\text { award. }\end{array}$ \\
\hline $\begin{array}{l}\text { 6. After Twenty } \\
\text { Years }\end{array}$ & $\begin{array}{l}\text { Written task+Oral task } \\
\text { Group work }\end{array}$ & $\begin{array}{l}\text { a. Students were redistributed for various duties based on their own } \\
\text { interests ranging from directors, actors and actress,playwrights, } \\
\text { producers to editors and costumes. } \\
\text { b. Six playwrights were to re-composite the story and make it as a } \\
\text { play. Costume groups were in charge of their make-ups and } \\
\text { costumes. } \\
\text { c. This task had been sponsored by local commercials for } \\
\text { producing the movie. } \\
\text { d. After the movie was done, students post it on a We-chat account } \\
\text { and repost it in their moments. }\end{array}$ \\
\hline $\begin{array}{l}\text { 7. Mandela's } \\
\text { Garden }\end{array}$ & $\begin{array}{l}\text { Oral task } \\
\text { Group work }\end{array}$ & $\begin{array}{l}\text { a. Each group was required to grow a plant for their own within } \\
\text { one and half month. } \\
\text { b. Each group made a presentation about the plant on its type, how } \\
\text { was it grown and what do they learn from this gardening } \\
\text { experience. }\end{array}$ \\
\hline $\begin{array}{l}\text { 8. Winter Break } \\
\text { Homework }\end{array}$ & $\begin{array}{l}\text { 1. My Hometown } \\
\text { Oral task } \\
\text { Group work }\end{array}$ & $\begin{array}{l}\text { 1. Each student was required to introduce his/her hometown by } \\
\text { interviewing foreigners living their. } \\
\text { 2. Make a video recording and present it back to class. }\end{array}$ \\
\hline $\begin{array}{l}\text { 9. Describing } \\
\text { places }\end{array}$ & $\begin{array}{l}\text { 1. Make a poster of } \\
\text { Mauritius } \\
\text { Written task } \\
\text { Group work }\end{array}$ & $\begin{array}{l}\text { 1. Each group was asked to make a poster of Mauritius based on } \\
\text { the information provided in the text or resources they searched } \\
\text { online. } \\
\text { 2. Pictures of all posters will be put in the Wechat public platform } \\
\text { for voting. The one gets highest votes will be rewarded as "The } \\
\text { Best Poster" }\end{array}$ \\
\hline
\end{tabular}

\section{Copyrights}

Copyright for this article is retained by the author(s), with first publication rights granted to the journal.

This is an open-access article distributed under the terms and conditions of the Creative Commons Attribution license (http://creativecommons.org/licenses/by/4.0/). 